\title{
18 \\ PEMBERDAYAAN MASYARAKAT PROGRAM KEMITRAAN PT.TELEKOMUNIKASI INDONESIA (TbK)
}

\author{
Oleh: \\ Fitri Ismail, Soni Akhmad Nurhakim dan Hadiyanto A. Rachim
}

E-mail:

fitriismai18@gmail.com, soninulhaqim@unpad.ac.id \& hrachim@yahoo.co.id

\begin{abstract}
ABSTRAK, Indonesia merupakan negara dengan penduduk terbesar ke-empat di dunia. Berdasarkan data hasil sensus oleh Badan Pusat statistik(BPS) tahun 2010 menunjukkan total penduduk Indonesia adalah sebesar 237.641.326 juta pada tahun 2010 dan jika dibandingkan dengan data statistiK sebelumnya pada tahun 2000 sebesar 206.264.295 juta. Saat ini banyak bermunculan ide-ide pembangunan bahwa pemerintah seharusnya dapat menggunakan pendekatan bottom up dalam membuat program artinya program yang dibuat oleh pemerintah berbasiskan kebutuhan masyarakatnya, karena pada dasarnya masyarakat lebih tahu apa yang mereka butuhkan, masyarakat pun lebih tau tentang masalah dan solusi terhadap permasalahan mereka hanya saja masyarakat tidak memiliki daya untuk melakukan solusi tersebut akibat adanya ketidakberdayaan masyarakat baik berupa pengetahuan, minimnya kesempatan dan akses memperoleh informasi dalam mewujudkan aspirasi mereka. Sehingga, pemerintah pun mewajibkan perusahaan BUMN atau pun swasta untuk mewujudkan 3 pilar pembangunan Indonesia (triple tracks) dan merupakan janji politik kepada masyarakat, yaitu: (1) pengurangan jumlah pengangguran (pro-job) (2) pengurangan jumlah penduduk miskin (propoor) dan (3) peningkatan pertumbuhan ekonomi (pro-growth). Menanggapi kewajiban tersebut, Kementrian BUMN membentuk Program Kemitraan dan Bina Lingkungan (PKBL) yang diatur dalam Peraturan Mentri BUMN No. PER -08/MBU/2013 tentang Program Kemitraan BUMN dengan usaha kecil dan Program Bina Lingkungan. Tujuan utama dari program kemitraan adalah menciptakan keberdayaan masyarakat untuk berkuasa dan memiliki daya dalam mengembangkan komunitas mereka dan mereka berpartisipasi dalam kegiatan tersebut.
\end{abstract}

Kata Kunci: Pembangunan, kemitraan, Usaha kecil, Keberdayaan, dan partisipasi, Social Empowerment Partnership

ABSTRACT, Indonesia is the country with the fourth largest population in the world. Today many emerging development ideas that the government should be able to use a bottom-up approach in making the program created by the government based on the needs of the people, because basically people prefer to know what they need, even more people know about the problem and the solution to the problems they just society does not have the power to carry out such solutions as a result of the powerlessness of the community in the form of knowledge, lack of opportunity and access to information in realizing their aspirations. Thus, the government requires that state-owned enterprises or private to manifest three pillars of Indonesia (triple tracks) and a political promise to the public. Responding to these obligations, the Ministry of SOEs to form the Partnership Program and Community Development (CSR) which is stipulated in the Regulation of Minister of SOE No. PER 08 / MBU / 2013 on SOE Partnership Program with Small Business and Community Development 
Program. The main objective of the partnership program is to create community empowerment to rule and have power in developing their communities and their participation in these activities.

Key Word: Development, Partnership, small business, empowerment and Participate

\section{PENDAHULUAN}

Indonesia merupakan negara dengan penduduk terbesar ke-empat di dunia saat ini setelah Cina, India dan Amerika serikat. Berdasarkan data hasil sensus oleh Badan Pusat statistik(BPS) tahun 2010 menunjukkan total penduduk Indonesia adalah sebesar 237.641.326 juta pada tahun 2010 dan jika dibandingkan dengan data statistiK sebelumnya pada tahun 2000 sebesar 206.264.295 juta. Angka ini menunjukkan bahwa Indonesia memiliki potensi terhadap segi kuantitas penduduknya. Namun seiring dengan meningkatnya laju pertumbuhan penduduk Indonesia saat ini, kita juga harus memperhatikan mengenai kualitas dari penduduk tersebut. Perhatian terhadap peningkatan kualitas penduduk dapat diukur melalui indeks pembangunan manusia (IPM) negara Indonesia.

Pemerintah telah berupaya untuk mewujudkan penduduk yang berkualitas melalui beberapa aktivitas yang diwujudkan dalam programprogram pembangunan Indonesia. Secara garis besar, inti dari pembangunan yang ingin diwujudkan oleh pemerintah sejak awal kemerdekaan yang termaktub dalam amanat Pembukaan Undang-undang Dasar 1945 alinea ke-4 yaitu:

"kemudian dari pada itu untuk membentuk suatu Pemerintahan Negara Indonesia yang melindungi segenap bangsa Indonesia dan seluruh tumpah darah Indonesia dan untuk memajukan kesejahteraan umum, mencerdaskan kehidupan bangsa, dan ikut melaksanakan ketertiban dunia yang berdasarkan kemerdekaan dan perdamaian abadi dan keadilan sosial, maka disusunlah Kemerdekaan Kebangsaan Indonesia itu dalam satu Undang-undang Dasar Negara Indonesia yang terbentuk dalam suatu susunan negara Republik Indonesia yang berkedaulatan rakyat dengan berdasarkan kepada Ketuhanan Yang
Maha Esa, kemanusian yang adil dan beradab, persatuan Indonesia, dan kerakyatan yang dipimpin oleh hikmat kebijaksanaan dalam permusyawaratan/perwakilan, serta dengan mewujudkan suatu keadilan sosial bagi seluruh rakyat Indonesia.

Dalam(http://www.itjen.depkes.go.id/) diunduh pada 29 April 2015.

Program-program yang dimunculkan oleh pemerintah pun dengan jelas ingin mewujudkan pembangunan yang berkualitas bagi masyarakatnya baik dalam bidang kesehatan, pendidikan dan ekonomi, karena ketiga indikator tersebut dapat menjadi tolak ukur untuk menilai kemajuan sebuah negara. Saat ini banyak bermunculan ide-ide pembangunan bahwa pemerintah seharusnya dapat menggunakan pendekatan bottom up dalam membuat program artinya program yang dibuat oleh pemerintah berbasiskan kebutuhan masyarakatnya, karena pada dasarnya masyarakat lebih tahu apa yang mereka butuhkan, masyarakat pun lebih tau tentang masalah dan solusi terhadap permasalahan mereka hanya saja masyarakat tidak memiliki daya untuk melakukan solusi tersebut akibat adanya ketidakberdayaan masyarakat baik berupa pengetahuan, minimnya kesempatan dan akses memperoleh informasi dalam mewujudkan aspirasi mereka. Sehingga pada akhirnya program-program yang dibuat oleh pemerintah untuk meningkatkan kualitas dari penduduknya menjadi tidak terlaksana seperti yang diharapkan.

Sehingga, pemerintah pun mewajibkan perusahaan BUMN atau pun swasta untuk mewujudkan 3 pilar pembangunan Indonesia (triple tracks) dan merupakan janji politik kepada masyarakat, yaitu: (1) pengurangan jumlah pengangguran (pro-job) pengurangan jumlah penduduk miskin (propoor) dan (3) peningkatan pertumbuhan ekonomi (pro-growth). Menanggapi 
kewajiban tersebut, Kementrian BUMN membentuk Program Kemitraan dan Bina Lingkungan (PKBL) yang diatur dalam Peraturan Mentri BUMN No. PER 08/MBU/2013 tentang Program Kemitraan BUMN dengan usaha kecil dan Program Bina Lingkungan. Hal ini terkait dengan tujuan pendirian BUMN tidak hanya mengejar keuntungan melainkan turut aktif memberikan bimbingan dan bantuan kepada pengusaha golongan ekonomi lemah.

PT. Telekomunikasi Indonesia (tbk) atau disingkat Telkom merupakan perusahaan Badan Usaha Milik Negara (BUMN) yang bergerak di bidang jasa layanan telekomunikasi dan jaringan di wilayah Indonesia dan karenanya tunduk pada hukum dan peraturan yang berlaku di Indonesia. (http://pkbl-telkom.com/). Telkom adalah salah satu perusahaan BUMN yang telah dan masih melaksanakan program kemitraan dan bina lingkungan. Dan merupakan salah satu perusahaan BUMN yang berhasil dalam melaksanakan Pogram kemitraan melalui upaya pemberdayaan masyasrakat.

\section{HASIL DAN PEMBAHASAN}

\section{Pemberdayaan}

Konsep pemberdayaan masyarakat yang ditawarkan oleh para akademisi sosial dalam membantu pemerintah mewujudkan pembangunan ekonomi masyarakat. Pemberdayaan menurut Simon (1990) yaitu suatu aktivitas refleksif, suatu proses yang mampu diinisiakan dan dipertahankan hanya oleh agen atau subjek yang mencari kekuatan atau penentuan diri sendiri (self-determination, sementara proses lainnya hanya dengan memberikan iklim, hubungan, sumber-sumber dan alat-alat prosedural yang melaluinya masyarakat dapat meningkatkan kehidupannya.

Pemberdayaan menurut Kartasasmita (1995) dapat dilakukan melalui tiga proses yaitu: Pertama: Menciptakan suasana atau iklim yang memungkinkan potensi masyarakat berkembang (enabling). Titik tolaknya adalah bahwa setiap manusia memiliki potensi yang dapat dikembangkan. Artinya tidak ada sumberdaya manusia atau masyarakat tanpa daya. Dalam konteks ini, pemberdayaan adalah membangun daya, kekuatan atau kemampuan, dengan mendorong (encourage) dan membangkitkan kesadaran (awareness) akan potensi yang dimiliki serta berupaya mengembangkannya. Kedua, memperkuat potensi atau daya yang dimiliki oleh masyarakat (empowering), sehingga diperlukan langkah yang lebih positif, selain dari iklim atau suasana. Ketiga, memberdayakan juga mengandung arti melindungi. Dalam proses pemberdayaan, harus dicegah yang lemah menjadi bertambah lemah, oleh karena kekurang berdayaannya dalam menghadapi yang kuat.

Sementara itu, Robert Chambers, seorang ahli yang pemikiran dan penelitiannya banyak dicurahkan untuk kepentingan upaya-upaya pemberdayaan masyarakat dalam Kartasasmita (1997:10, dalam Huraerah, 2011: 95) berpendapat bahwa pemberdayaan masyarakat adalah sebuah konsep pembangunan ekonomi yang merangkum nilai-nilai sosial. Konsep pemberdayaan mencerminkan paradigm baru pembangunan, yakni bersifat "people-centered, participatory, empowering, and sustainable" konsep ini lebih luas dari hanya semata-mata memenuhi kebutuhan dasar (basic needs) atau menyediakan mekanisme untuk mencegah proses pemiskinan lebih lanjut (safety net).

Kemudian Soetarso (2003) menjelaskan bahwa pemberdayaan masyarakat pada hakikatnya mempunyai dua pengertian yang saling berkaitan yaitu: a) peningkatan kemampuan, motivasi dan peran semua unsur masyarakat agar dapat menjadi sumber langgeng untuk mendukung semua bentuk usaha kesejahteraan sosial. b) pemanfaatan sumber masyarakat yang telah ditingkatkan kemampuan motivasi, dan perannya. Dalam persepektif Pekerja sosial, menurut Jim Ife 
dalam Suharto (2005: 59) pemberdayaan memuat dua pengertian kunci, yakni kekuasaan dan kelompok lemah. Kekuasaan disini diartikan bukan hanya menyangkut kekuasaan politik dalam arti sempit melainkan kekuasaan atau penguasaan klien atas:

a. Pilihan-pilihan personal dan kesempatankesempatan hidup: kemampuan dalam membuat keputusan-keputusan mengenai gaya hidup, tempat tinggal, pekerja

b. Pendefinisian kebutuhan; kemampuan menentukan kebutuhan selaras dengan aspirasi dan keinginannya.

c. Lembaga-lembaga: kemampuan menjangkau, menggunakan dan mempenagruhi pranata-pranata masyarakat, seperti lembaga kesejahteraan sosial, pendidikan, kesehatan.

d. Ide atau gagasan: kemampuan mengekspresikan dan menyumbangkan gagasan dalam suatu forum atau diskusi secara bebas dan tanpa tekanan.

e. Sumber-sumber: kemampuan memobilisasi sumber-sumber formal, informal dan kemasyarakatan.

f. Aktivitas ekonomi: kemampuan memanfaatkan dan mengelola mekanisme produksi, distribusi dan pertukaran barang serta jasa.

g. Reproduksi: kemampuan dalam kaitannya dengan proses kelahiran, perawatan anak, pendidikan dan sosialisasi.

Tujuan dasar pemberdayaan adalah keadilan sosial dengan memberikan ketentraman kepada masyarakat yang lebih besar serta persamaan politik dan sosial melalui upaya saling membantu dan belajar melalui pengembangan langkah-langkah kecil guna tercapainya tujuan yang lebih besar, Payne (1997) dalam Huraerah: 2011.

Kemudian, Sulistiyani (2004) menjelaskan bahwa tujuan yang ingin dicapai dari pemberdayaan masyarakat adalah untuk membentuk individu dan masyarakat menjadi mandiri. Kemandirian tersebut meliputi kemandirian berpikir, bertindak dan mengendalikan apa yang mereka lakukan. Kemandirian masyarakat merupakan suatu kondisi yang dialami oleh masyarakat yang ditandai dengan kemampuan memikirkan, memutuskan sertamelakukan sesuatu yang dipandang tepat demi mencapai pemecahan masalah yang dihadapi dengan mempergunakan daya/kemampuan yang dimiliki. (Maharani, 2012)

Payne (1997) dalam Maharani (2012) menjelaskan bahwa pemberdayaan pada hakekatnya bertujuan untuk membantu klien mendapatkan daya, kekuatan dan kemampuan untuk mengambil keputusan dan tindakan yang akan dilakukan dan berhubungan dengan diri klien tersebut, termasuk mengurangi kendala pribadi dan sosial dalam melakukan tindakan. Orang-orang yang telah mencapai tujuan kolektif diberdayakan melalui kemandiriannya, bahkan merupakan "keharusan" untuk lebih diberdayakan melalui usaha mereka sendiri dan akumulasi pengetahuan, ketrampilan serta sumber lainnya dalam rangka mencapai tujuan tanpa tergantung pada pertolongan dari hubungan eksternal.\&nbsp;

Tujuan pemberdayaan masyarakat memperkuat kekuasaan masyarakat khususnya kelompok lemah yang berada dalam ketidakberdayaan. Sebagai tujuan dari pemberdayaan UKM adalah untuk memperkuat usaha UKM agar menjadi tangguh dan mandiri, sehingga dapat menghadapi perdagangan bebas yang bertujuan untuk meningkatkan laju pertumbuhan perekonomian Indonesia. (Nurul, 2011). Kemudian Suharto (1997) menjelaskan bahwa tujuan pemberdayaan adalah suatu keadaan yang ingin dicapai, yakni klien yang memiliki kekuasaan atau keberdayaan yang mengarah pada kemandirian sesuai dengan tipe-tipe kekuasaannya. 
Prinsip dan Asumsi Pemberdayaan

Dubois dan Miley dalam memberi beberapa prinsip pemberdayaan masyarakat yaitu sebagai berikut:

1. Membangun relasi pertolongan yang: a) merefleksikan respon empati, b) menghargai pilihan dan hak klien menentukan nasibnya sendiri (self determination), c) menghargai perbedaan dan keunikan individu, 4) menekankan kerjasama klien (client partnership)

2. Membangun komunikasi yang: a) menghormati martabat dan harga diri klien, b) mempertimbangkan keragaman individu, c) berfokus pada klien, 4) menjaga kerahasiaan klien.

3. Terlibat dalam pemecahan masalah yang: a)memperkuat partisipasi klien dalam semua aspek proses pemecahan maslaah, b) menghargai hak-hak klien, c) merangkai tantangan sebagai kesempatan belajar, d) melibatkan klien dalam pembuatan keputusan dan evaluasi

4. Merefleksikan sika dan nilai profesi pekerjaaan sosial melalui; a) ketataatan terhadap kode etik profesi, b) keterlibatan dalam pengembangan professional, riset dan perumusan kebijakan, c) penerjemahan kesulitan-kesulitan pribadi ke dalam isu public, d) penghapusan segala bentuk diskriminasi dan ketidaksetaraan kesempatan (Suharto, 2005:68)

Strategi Pemberdayaan Masyarakat

Pada setiap pelaksanaan pemberdayaan masyarakat terdapat strategi-strategi pemberdayaan, menurut Mark G. Hanna dan Buddy Robinson (1994) menyebutkan terdapat tiga macam strategi utama pemberdayaan dalam praktek perubahan sosial dan faktorfaktor determinan yang mempengaruhinya:

1. Strategi tradisional, yang menyarankan agar mengetahui dan memilih kepentingan terbaik secara bebas dalam berbagai keadaan.
2. Strategi direct-action, yang membutuhkan dominansi kepentingan yang dihormati oleh semua pihak yang terlibat, dipandang dari sudut perubahan yang mungkin terjadi.

3. Strategi transformatif, yang menunjukkan bahwa pendidikan dalam jangka panjang dibutuhkan sebelum pengidentifikasian kepentingan diri sendiri.

Kemudian strategi pemberdayaan juga dikemukakan oleh Jim Ife (1995: 61-64 dalam Suharto 1997: 217-218) yang mana pemberdayaan memuat dua kunci, yakni kekuasaan dan kelompok lemah. Kekuasaan disini diartikan bukan hanya menyangkut kekuasaan politik dalam arti sempit, melainkan kekuasaan atau penguasaan klien atas:

1. Pilihan-pilihan personal dan kesempatankesempatan hidup (power over personal choices and life chances), kemampuan dalam membuat keputusan-keputusan mengenai gaya hidup, tempat tinggal, pekerjaan.

2. Pendefinisian kebutuhan (power over definition of need), kemampuan menentukan kebutuhan selaras dengan aspirasi dan keinginannya.

3. Ide atau gagasan (power over ideas), kemampuan mengeksprisikan dan menyumbangkan gagasan dalam suatu forum atau diskusi secara bebas dan tanpa tekanan.

4. Lembaga-lembaga (power over institutions), kemampuan menjangkau, menggunakan dan mempengaruhi prantapranata

5. Sumber-sumber (power over resources), kemampuan memobilisasi sumber-sumber formal, informal dan kemasyarakatan;

6. Aktivitas ekonomi (power over economic activity), kemampuan memanfaatkan dan mengolola meanisme produksi, distribusi, dan pertukaran barang serta jasa.

7. Reproduksi (power over reproduction), kemampuan dalam kaitannya dengan 
proses kelahiran, perawatan anak, pendidikan dan sosialisasi)

Sementara itu kategori kelompok lemah atau tidak beruntung meliputi:

1. Kelompok lemah secara structural (primary structural disadvantaged groups), baik secara kelas, gender, maupun etnis;

2. Kelompok lemah khusus (other disadvantaged groups), seperti manula, anak-anak dan remaja, penyandang gay dan lesbian, masyarakat terasing; dan

3. Kelompok lemah secara personal (the personally disadvantaged), adalah mereka yang mengalami masalah pribadi, keluarga.

Dari pemaparan strategi dalam pemberdayaan masyarakat dapat disimpulkan bahwa strategi pemberdayaan masyarakat adalah suatu model kegiatan yang dilaksanakan oleh enabler (pemercepat perubahan) selaras dengan tujuan pemberdayaan yaitu upaya-upaya yang dilakukan untuk membuat masyarakat lebih berdaya dan memiliki kekuasaan atas kehidupan mereka.

Partisipasi dalam Pemberdayaan Masyarakat

Partisipasi merupakan bagian terpenting dalam pemberdayaan masyarakat. Banyak pengertian partisipasi telah dikemukakan oleh para ahli, namun pada hakekatnya memiliki makna yang sama. Partisipasi berasal dari bahasa Inggris participate yang artinya mengikutsertakan, ikut mengambil bagian (Willie Wijaya, 2004:208). Pengertian yang sederhana tentang partisipasi dikemukakan oleh Fasli Djalal dan Dedi Supriadi (2001: 201-202), dimana partisipasi dapat juga berarti bahwa pembuat keputusan menyarankan kelompok atau masyarakat ikut terlibat dalam bentuk penyampaian saran dan pendapat, barang, keterampilan, bahan dan jasa. Partisipasi juga berarti bahwa kelompok mengenal masalah mereka sendiri, mengkaji pilihan mereka, membuat keputusan, dan memecahkan masalahnya.

H.A.R. Tilaar

(2009:287)

mengungkapkan partisipasi adalah sebagai wujud dari keinginan untuk mengembangkan demokrasi melalui proses desentralisasi dimana diupayakan antara lain perlunya perencanaan dari bawah (button-up) dengan mengikutsertakan masyarakat dalam proses perencanaan dan pembangunan masyarakatnya. Menurut Soegarda Poerbakawatja partisipasi adalah: Suatu gejala demokrasi dimana orang diikutsertakan di dalam perencanaan serta 13 pelaksanaan dari segala sesuatu yang berpusat pada kepentingan dan juga ikut memikul tanggung jawab sesuai dengan tingkat kematangan dan tingkat kewajibannya (Soegarda Poerbakawatja, 1981:251). Partisipasi menurut I Nyoman Sumaryadi (2010) adalah peran serta seseorang atau kelompok masyarakat dalam proses pembangunan baik dalam bentuk pernyataan maupun dalam bentuk kegiatan dengan memberi masukan pikiran, tenaga, waktu, keahlian, modal dan atau materi, serta ikut memanfaatkan dan menikmati hasil hasil pembangunan.

Berdasarkan pengertian yang telah disebutkan, konsep partisipasi memiliki makna yang luas dan beragam. Secara garis besar dapat ditarik kesimpulan partisipasi adalah suatu wujud dari peran serta masyarakat dalam aktivitas berupa perencanaan dan pelaksanaan untuk mencapai tujuan pembangunan masyarakat. Wujud dari partisipasi dapat berupa saran, jasa, ataupun dalam bentuk materi baik secara langsung maupun tidak langsung dalam suasana demokratis.

\section{Macam- Macam Partisipasi}

Ada beberapa macam partisipasi yang dikemukakan oleh ahli. Menurut Sundariningrum (Sugiyah, 2010:38) mengklasifikasikan partisipasi menjadi dua berdasarkan keterlibatannya, yaitu:

a. Partisipsai langsung 
Partisipasi yang terjadi apabila individu menampilkan kegiatan tertentu dalam proses partisipasi. Partisipasi ini terjadi apabila setiap orang dapat mengajukan pandangan, membahas pokok permasalahan, mengajukan keberatan terhadap keinginan orang lain atau terhadap ucapannya.

\section{b. Partisipasi tidak langsung}

Partisipasi yang terjadi apabila individu mendelegasikan hak partisipasinya pada orang lain.

Pendapat lain disampaikan oleh Subandiyah (1982:2) yang menyatakan bahwa jika dilihat dari segi tingkatannya partisipasi dibedakan menjadi tiga yaitu:

a. Partisipasi dalam pengambilan keputusan

b. Partisipasi dalam proses perencanaan dan kaitannya dengan program lain.

c. Partisipasi dalam pelaksanaan.

Lebih rinci Cohen dan Uphoff (Siti Irene A.D., 2011:61) membedakan partisipasi menjadi empat jenis yaitu pertama, partisipasi dalam pengambilan keputusan. Kedua, partisipasi dalam pelaksanaan. Ketiga, partisipasi dalam pengambilan manfaat. Dan keempat, partisipasi dalam evaluasi. Pertama, partisipasi dalam pengambilan keputusan. Partisipasi ini terutama berkaitan dengan penentuan alternatif dengan masyarakat yang berkaitan dengan gagasan atau ide yang menyangkut kepentingan bersama. Dalam partisipasi ini masyarakat menuntut untuk ikut menentukan arah dan orientasi pembangunan. Wujud dari partisipasi ini antara lain seperti kehadiran rapat, diskusi, sumbangan pemikiran, tanggapan atau penolakan terhadap program yang ditawarkan. Kedua, partisipasi dalam pelaksanaan suatu program meliputi: menggerakkan sumber daya, dana, kegiatan administrasi, koordinasi dan penjabaran program. Ketiga, partisipasi dalam pengambilan manfaat. Partisipasi ini tidak lepas dari hasil pelaksanaan 15 program yang telah dicapai baik yang berkaitan dengan kuantitas maupun kualitas. Dari segi kualitas, dapat dilihat dari peningkatan output, sedangkan dari segi kuantitas dapat dilihat seberapa besar prosentase keberhasilan program. Keempat, partisipasi dalam evaluasi. Partisipasi masyarakat dalam evaluasi ini berkaitan dengan masalah pelaksanaan program secara menyeluruh. Partisipasi ini bertujuan untuk mengetahui ketercapaian program yang telah direncanakan sebelumnya.

Dari pendapat di atas dapat disimpulkan macam partisipasi, yaitu:

a. Partisipasi dalam proses perencanaan/ pembuatan keputusan. (Participation in decision making).

b. Partisipasi dalam pelaksanaan (participation in implementing)

c. Partisipasi dalam pemanfaatan hasil

d. Partisipasi dalam evaluasi (participation in benefits)

\section{Kemitraan}

Menurut Hafsah (2000) dalam jurnalnya menyebutkan bahwa kemitraan merupakan suatu strategi bisnis yang dilakukan oleh dua pihak atau lebih dalam jangka waktu tertentu untuk meraih keuntungan bersama dengan prinsip saling membutuhkan dan saling membesarkan.

\section{Model-model Kemitraan}

Model kemitraan oleh Sulistyani (2004) diilhami dari fenomena biologis kehidupan organisme dan mencoba mengangkat ke dalam pemahaman yang kemudian dibedakan menjadi:

a. Pseudo partnership, atau kemitraan semu merupakan kerjasama antara dua pihak atau lebih namun tidak sesungguhnya melakukan kerjasama yang seimbang antara yang satu dengan lainnya.

b.Mutualism partnership, atau kemitraan mutualistik merupakan kerjasama dua pihak Jurnal Administrasi Publik (JAP), Vol. 1, No. 5, Hal. 953-961 | 956 atau lebih yang sama- 
sama menyadari aspek pentingnya melakukan kemitraan yaitu untuk saling memberikan manfaat lebih sehingga tercapai tujuan secara optimal.

c.Conjungtion partnership, atau kemitraan melalui peleburan dan pengembangan merupakan kemitraan yang dianalogikan dari kehidupan "paramecium". Dalam proses kehidupannya, "paramecium" melakukan konjungsi untuk mendapatkan energi dan kemudian terpisah untuk selanjutnya dapat melakukan pembelahan diri.

Adapun model kemitraan yang lain yang dikembangkan berdasar atas azas kehidupan organisasi pada umumnya yaitu:

a. Subordinate union of partnership, kemitraan semacam ini terjadi antara dua pihak atau lebih yang memiliki status, kemampuan, atau kekuatan yang tidak seimbang satu sama lain.

b. Linear Union of partnership, kerjasama ini dilakukan oleh organisasi atau para pihak yang memiliki persamaan secara relatif, baik tujuan, misi, besaran/volume usaha atau organisasi, status, dan legalitas.

c. Linear Collaborative of partnership, kemitraan ini tidak membedakan besaran atau volume, status/legalitas, atau kekuatan para pihak yang bermitra. Yang menjadi tekanan utama adalah visi-misi yang saing mengisi satu dengan yang lainnya.

\section{Pola-pola Kemitraan}

No. 20 tahun 2008 terdapat enam pola yang mungkin dilakukan dalam pelaksanaan kemitraan diantaranya:

a. Pola Inti-Plasma;

b. Pola Sub-Kontrak;

c. Pola Dagang Umum;

d. Pola Waralaba;

e. Pola Keagenan; dan

f. Pola lain-lain

Bentuk Kemitraan

Tabel 2.1 Bentuk kemitraan BUMN

\begin{tabular}{|c|c|}
\hline \multicolumn{2}{|r|}{ Bentuk Kemitraan } \\
\hline $\begin{array}{l}\text { Bantuan } \\
\text { Pinjaman } \\
\text { Dana }\end{array}$ & $\begin{array}{l}\text { 1. Modal kerja dan atau } \\
\text { 2. Pembelian barang-barang Modal ( aktiva tetap } \\
\text { produktif) } \\
\text { 3. Pinjaman khusus bersifat jangka pendek ( maksimal } 1 \\
(\text { satu) tahun) }\end{array}$ \\
\hline $\begin{array}{l}\text { Hibah atau } \\
\text { (Pembinaaan) }\end{array}$ & 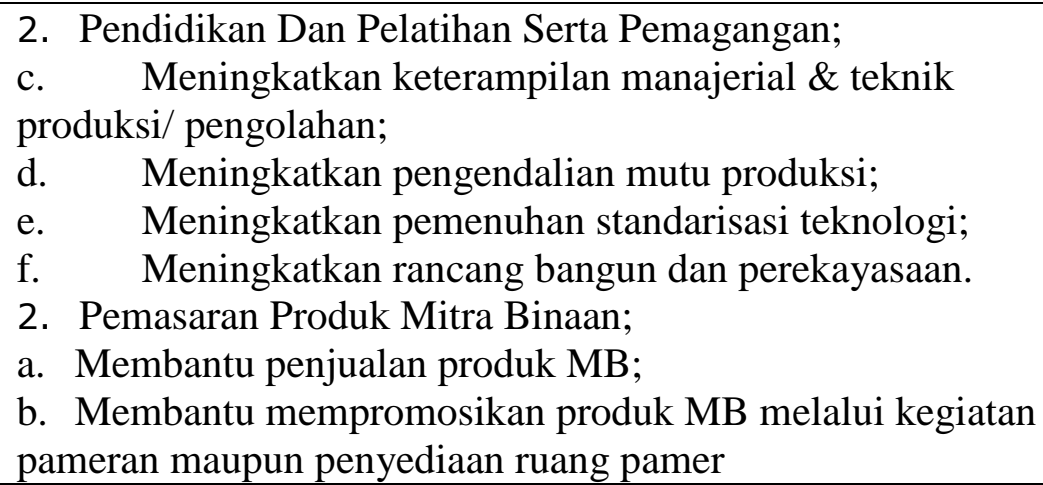 \\
\hline
\end{tabular}

\section{Program Kemitraan}

Dalam pelaksanaan Program Kemitraan BUMN dilandasi per-05/mbu/2007 tanggal 27 april 2007 tentang program kemitraan badan usaha milik negara dengan usaha kecil dan program bina lingkungan. Berikut adalah penjelasannya: 
Program Kemitraan adalah program untuk meningkatkan kemampuan usaha kecil agar menjadi tangguh dan mandiri melalui pemanfaatan dana dari bagian laba BUMN. Usaha Kecil yang dapat ikut serta dalam Program Kemitraan adalah sebagai berikut:

1. Memiliki kekayaan bersih paling banyak Rp.200.000.000,- (dua ratus juta rupiah), tidak termasuk tanah dan bangunan tempat usaha; atau

2. Memiliki hasil penjualan tahunan paling banyak Rp. 1.000.000.000,- (satu milyar rupiah);

3. Milik Warga Negara Indonesia;

4. Berdiri sendiri, bukan merupakan anak perusahaan atau cabang perusahaan yang dimiliki, dikuasai, atau berafiliasi baik langsung maupun tidak langsung dengan Usaha Menengah atau Usaha Besar;

5. Berbentuk usaha orang perseorangan, badan usaha yang tidak berbadan hukum, atau badan usaha yang berbadan hukum, termasuk koperasi.

6. Telah melakukan kegiatan usaha minimal 1 (satu) tahun serta mempunyai potensi dan prospek usaha untuk dikembangkan.

Mitra Binaan mempunyai kewajiban sebagai berikut:

1. Melaksanakan kegiatan usaha sesuai dengan rencana yang telah disetujui oleh BUMN Pembina;

2. Menyelenggarakan pencatatan/pembukuan dengan tertib;

3. Membayar kembali pinjaman secara tepat waktu sesuai dengan perjanjian yang telah disepakati;

4. Menyampaikan laporan perkembangan usaha setiap triwulan kepada BUMN Pembina.

Sektor Usaha yang dapat diberikan bantuan pinjaman adalah Industri, Jasa, Perdagangan,
Peternakan, Perikanan, Pertanian, Perkebunan dan Jasa lainnya.

\section{Usaha Kecil}

Usaha kecil adalah kegiatan ekonomi rakyat yang berskala kecil dan memenuhi kriteria kekayaan bersih atau hasil penjualan tahunan serta kepemilikan sebagaimana diatur dalam Keputusan Telkom. (Dalam situs web pkbltelkom.com)

Usaha Kecil adalah usaha ekonomi produktif yang berdiri sendiri, yang dilakukan oleh orang perorangan atau badan usaha yang bukan merupakan anak perusahaan atau bukan cabang perusahaan yang dimiliki, dikuasai, atau menjadi bagian baik langsung maupun tidak langsung dari usaha menengah atau usaha besar yang memenuhi kriteria Usaha Kecil sebagaimana dimaksud dalam UndangUndang ini. (Undang- Undang Nomor 20 Tahun 2008 tentang Usaha Mikro, Kecil dan Menengah UMKM)

Tabel 2.1. Kriteria Usaha Mikro, Kecil dan Menengah

\begin{tabular}{|c|l|c|c|}
\hline \multirow{2}{*}{ No } & \multirow{2}{*}{ URAIAN } & \multicolumn{2}{|c|}{ KRITERIA } \\
\cline { 3 - 4 } & & ASSET & OMZET \\
\hline 1 & \multirow{2}{*}{ Usaha Mikro } & Max $50 \mathrm{jt}$ & Max $300 \mathrm{jt}$ \\
\hline 2 & Usaha Kecil & $>50 \mathrm{jt}-500 \mathrm{jt}$ & $>300 \mathrm{jt}-2.5 \mathrm{~m}$ \\
\hline 3 & Usaha Menengah & $>50 \mathrm{jt}-10 \mathrm{~m}$ & $2.5 \mathrm{~m}-50 \mathrm{~m}$ \\
\hline
\end{tabular}

Sumber: www.depkop.go.id diunduh pada 13 April 2015

\section{Definisi Mitran Binaan}

Mitra Binaan adalah Usaha Kecil yang mendapatkan pinjaman dari Program Kemitraan. (Dalam situs web pkbltelkom.com)

Mitra binaan adalah usaha kecil dan koperasi yang mendapatkan pinjaman dari Program 
Kemitraan. Mitra binaan mempunyai kewajiban sebagai berikut:

1. Melaksanakan kegiatan usaha sesuai dengan rencana yang telah disetujui oleh BUMN Pembina;

2. Menyelenggarakan pencatatan/pembukuan dengan tertib;

3. Membayar kembali pinjaman secara tepat waktu sesuai dengan perjanjian yang telah disepakati;

4. Menyampaikan laporan perkembangan usaha setiap triwulan kepada BUMN Pembina

Pelaksanaan program kemitraan diharapkan sesuai dengan tujuan pemberdayaan yaitu untuk memperkuat UKM agar menjadi tangguh dan mandiri, sehingga dapat menghadapi perdagangan bebas yang bertujuan untuk meningkatkan laju pertumbuhan perekonomian Indonesia. Mengingat pada tahun 2015 ini Indonesia telah memasuki pasar bebas ekonomi ASEAN. Usaha pemberdayaan UKM ini sebagai pendorong keberfungsian $\operatorname{sosial}^{8}$ dari suatu komunitas 9 .

Komunitas yang menjadi mitra binaan perusahaan BUMN harus memenuhi syaratsyarat yang telah ditentukan. Program kemitraan memerlukan partisipasi yang berkelanjutan sehingga komunitas yang telah dibangun bisa sampai pada tujuan pemberdayaan yaitu terciptanya komunitas yang mandiri.

Keberlanjutan komunitas sangat tergantung pada partisipasi dari anggota komunitas, sehingga mempermudah komunikasi dalam

\footnotetext{
${ }^{8}$ Keberfungsian sosial merujuk pada cara individu-individu atau kolektivitas seperti keluarga, perkumpulan, komunitas, dan sebagainya berperilaku untuk dapat melaksanakan tugas-tugas kehidupan kehidupan dan memenuhi kebutuhan-kebutuhan mereka. (Siporin, 1975 dalam Adi 2012)

${ }^{9}$ Pengertian komunitas mengacu pada sekumpulan orang yang saling berbagi perhatian, masalah atau kegemaran terhadap suatu topik dan memperdalam pengetahuan serta keahlian mereka dengan saling berinteraksi secara terus menerus (Wenger, 2002:4).
}

anggota komunitas atau dalam arti lain anggota masyarakat dapat terorganisir dengan baik lengkap dengan struktur yang mengikat anggota komunitas.

Proses pemberdayaan masyarakat pada suatu komunitas yang dilaksanakan sesuai dengan kebutuhannya berdasarkan hasil need assessment $^{10}$, dimana komunitas juga dapat memenuhi syarat-syarat yang telah ditentukan oleh perusahaan, terdapat kerja sama dalam bentuk partisipasi dari perusahaan dan komunitas yang kemudian dapat mewujudkan komunitas yang berkelanjutan dan mandiri.

Program kemitraan yang dijalankan oleh Telkom dinilai berhasil, keberhasilan ini terlhat dari sambutan Direktur utama Telkom (Arief Yahya) dalam laporan PKBL 2012 yang menyebutkan:

"Penyelenggaraan Program kemitraan selama tiga tahun terakhir terus mengalami peningkatan baik dari segi besaran nominal bantuan maupun jumlah mitra binaan. Sejak 2001 sampai dengan 31 Desember 2012 Program Kemitraan Telkom berhasil menyalurkan bantuan pinjaman kepada 89.771 Mitra Binaan di seluruh Indonesia dengan total penyaluran sebesar Rp 1.885,25 miliar. Pada 2012, Telkom telah berhasil menyalurkan dana melalui Program Kemitraan sebesar Rp 343,87 miliar untuk 9.346 Mitra Binaan, Program Pembinaan sebesar Rp 10,00 miliar dengan tingkat kolektabilitas pengembalian pinjaman sebesar Rp 308,23 miliar." (PKBL. dalam http://pkbl-telkom.com/) Kemudian terlihat juga pada penghargaan yang diperoleh adalah Telkom sebagai Inovasi PKBL-BUMN Terbaik di ajang Anugerah BUMN 2011.

10 NA digunakan untuk menentukan masalah-masalah dan tujuan-tujuan warga suatu masyarakat guna memastikan bahwa bentuk intervensi yang dilakukan akan menjawab kebutuhan populasi yang diambil sampelnya. (praktikum makro (pengembangan masyarakat. 2013) 


\section{SIMPULAN DAN SARAN}

Program kemitraan yang dilaksanakan oleh Telkom merupakan salah satu bentuk perwujudan kewajibannya sebagai perusahaan BUMN dalam menciptakan masyarkat yang tangguh dan mandiri. Program kemitraan Telkom dinilai berhasil dengan melihat semakin banyaknya masyarakat yang berminat untuk bergabung dalam program kemitraannya.

Program kemitraan yang dilaksanakan oleh Telkom adalah berbasis pengembangan masyarakat yang mengusung konsep pemberdayaan. Keberhasilan pemberdayaan dapat dilihat dari bagaimana tahapan dan strategi yang dilaksanakannya.

Telkom mengembangkan metode pemberdayaan yang berwujudkan atas adanya upaya masyarakat untuk mengembangkan usaha kecil dan menenagh, sehingga saat masyarakat memiliki hambatan dalam modal usaha, maka masyarakat dapat mengakses program kemitraan, dan masyarakat tersebut kemudian akan menjadi mitra binaan Telkom selama waktu maksimal pendampingan adalah 3 tahun.

Kemudian dalam waktu 3 tahun, Telkom akan mengukur keberhasilannya, sehingga sampai berbagai informasi yang dilaksanakan saat ini Telkom telah dinilai berhasil dengan penghargaan yang diperoleh pada tahun 2011 dan meningkatnya jumlah mitra binaan Telkom.

Namun seiring dengan keberhasilannya, Telkom belum menunjukkan kondisi nyata dari semuat mitra binaannya. Mitra binaan sukses dan tidak suksesnya, sehingga yang sering muncul hanyalah keberhasilannya padahal kesuksesan dan tidak suksesnya mitra binaan juga akan sangat terkait dengan bagaimana pendampingan dan monitoring dari Telkom terhadap mitra binaannya.

\section{DAFTAR PUSTAKA}

Depkop. Usaha Mikro, Kecil dan Menengah. Dalam, http://www.depkop.go.id/attachment s/article/129/259_KRITERIA_UU_U MKM_Nomor_20_Tahun_2008.pdf,) diunduh pada Senin, 13 April 2015)

Jim Ife. 2008. Community Development: Alternatif Pengembangan Masyarakat di Era Globalisasi. Yogyakarta: Pustaka Pelajar

Huraerah, 2011. Pengorganisasian dan Pengembangan Masyarakat, Model dan Strategi Pembenagunan berbasis Pemberdayaan. Bandung:Humaniora

Isbandi. 2012. Intervensi Komunitas \& Pengembangan Masyarakat: Sebagai Upaya Pemberdayaan Masyarakat. Jakarta: PT.Raja Grafindo Persada

PPSAT UGM. 2012. Konsep Dasar dan Teori Partisipasi.Dalamhttp://www.pssat.u gm.ac.id/index.php/id/publikasi/buku /129-konsep-konsep-dasarpartisipasi-sosial, diunduh tgl 07-122014

Suharto, Edi. 2010. CSR \& COMDEV: Investasi Kreatif Perusahaan Di Era Globalisasi. Bandung: Alfabeta

.2008. Pembangunan, Kebijakan Sosial, \& Pekerjaan Sosial. Bandung: LSP-STKS Bandung

, 2005. Membangun Masyarakat, Memberdayakan Rakyat. Bandung: Alfabeta

Telkom Indonesia. Community development center. (Dalam, http://pkbltelkom.com/portal/index.php) diunduh pada Minggu 12 April 2015

Wibawa, Budhi, Rudi S Darwis, Risna Resnawati dan Sahadi Humaedi. 2013. Panduan Pelaksanaan: Praktikum Pengembangan Masyarakat. Bandung. 